\title{
Questions on the Study of "The Communist Youth League and China Elite Politics" in Western Circles of Politics
}

\author{
Yunzhe Chen ${ }^{1,2}$ \\ ${ }^{1}$ Australia University of New South Wales, Australia \\ ${ }^{2}$ League Institute for Theoretical Work, China Youth University For Political Sciences (The Central Communist \\ Youth League), China \\ Correspondence: Yunzhe Chen, League Institute for Theoretical Work, China Youth University For Political \\ Sciences (The Central Communist Youth League), China. Tel: 86-138-2442-7900. E-mail: \\ chenyunzhe_sci@163.com
}

Received: April 28, 2014 Accepted: May 19, 2014 Online Published: August 25, 2014

doi:10.5539/jpl.v7n3p112 URL: http://dx.doi.org/10.5539/jpl.v7n3p112

\begin{abstract}
The role of the Chinese Communist Youth League within China's politics is significant. But, such important institution has received insufficient analysis for a long time. Since Hu Jintao's coming into power, a reasonable numbers of cadres, with the youth league working experience, have entered the China's elite politics. And this institution arouses the focus of Western scholars. However, limited by the bias and the misunderstanding, scholars from the Western political science regarded the youth league as the foundation of certain political faction, not an institution of assisting the elite circulation for the party. Under the purpose of deepening the understanding of the research approach of the English world, this article is going to systematically analyze the former researches of the youth league in Western world.
\end{abstract}

Keywords: communist youth league(CYL), informal politics, CYL faction

\section{Introduction}

Since the official foundation of Chinese Communist Youth League in May, 1922 (Guangzhou), there has been more than 90 years of glorious history. As a mass organization for advanced youth, Chinese Communist Youth League is a school for the youth to study socialism with Chinese characteristics and communism in practice, the assistant and reserve force for the Communist Party of China. It has always been closely united under the correct leadership of the Communist Party of China, from a small community, with 15 local youth league organizations and more than 5000 members in the early stage to (till 2007) about 75.439 million members, 191000 carders and 2.946 million youth league organizations at the grassroots and has become one of three people's groups with influence in China political society.(Note 1) The Youth League has not only well completed the tasks of our party in each historical period, but also provided many excellent young cadres for party and government organs of all levels, institutions, people's organizations, enterprises and other organizations. The Youth League is one of the most important institutions in Chinese political ecology, but relevant literature is rare in circles of domestic and international politics. In recent years, due to the active experiences of a large number of Communist Youth League carders in various fields of Chinese politics, the Youth League as a topic has attracted the attention of the circles of Western politics. Therefore, the author will introduce Western academic research on theoretical basis and research results of the Communist Youth League and put forwards some questions on existing achievements.

\section{Theoretical Research of Western Informal Politics}

\subsection{Background of the Rise of Informal Political Theory}

The Soviet Union was the first communist country, whose national system mainly presents the Leninist party structure (Shambaugh, 2008) and does not have the two-party or multiparty election system existing in most western countries. Therefore, the research of new Chinese political elites done by early Western political circles follows "totalitarianism"(Arendt, 1973; Friedirich \& Brzezinski, 1961; Schapiro, 1972; Tucker, 1965) according to the study of the Soviet Union and the research result focuses on the influence of the right operation and decision making by collective commonality of political elites and personality traits of leaders. However, with the outbreak of the Cultural Revolution, the highly unified situation among Chinese political elites is broken and 
more and more Chinese experts think that the study method of totalitarianism is inappropriate. Therefore, they begin to construct and develop three China elite political theories: first is to explore Generational Politics (Yahuda, 1979; Cherrington. 1997; Pye, 1976) among different generational elites formed by different important historical events; second is from the after-war American Technocracy, which is mainly used by Western political community to study the phenomenon that a large number of technocrats with science and engineering background enter into the core of China's politics (Li \& White, 1988; Li \& White, 1998; Zang, 1991; Zang, 1993, Kou, 2011) after the implementation of the "four modernization" cadre policy; third is the Informal Politics emphasizing the conflicts among political elites, or "Factionalism Politics"(Kou, 2010) in a narrow sense, which is the mainstream theory widely used in the Youth League and is also the main content of theoretical basis of Western Communist Youth League study in this thesis.

\subsection{Basic Concept of Theory of Informal Politics and Views of Main Scholars}

In Western political opinion, due to the "Nomenklatura System" in structure and the "Democratic Centralism" in decision mechanism, the traditional communist regime of Leninism type endows Chinese political elites highly centralized power and meanwhile the use of power lacks adequate supervision. Therefore, Informal Relationship becomes the key factor affecting Chinese elite politics and Faction is the basic unit for political elites to participate in political activities. However, there are different mainstream opinions on the definition of "Faction", the content of "informal relation" consisting factions, "the causes of factional politics" and "the game rules in factional struggle" and so on.

Specifically, on the concept of "Faction" and the content of "informal relationship", Samuel Huntington believes that "Faction" is essentially a kind of political connection, mainly in the period when the political participation and political institutional level is relatively low. (Huntington, 1989) Jorgen Domes first proposes factional model and in his opinion, Chinese political factors are mainly "Structural" Factions based on common experience and "Functional" Factions based on department interests (Bo, 2002). Andrew Nathan proposes Factionalism Model to explain the Patterns of Conflict and Coalition among political elites. He believes that the social network radiated from the leaders as the core, in which members have vertical relations between the upper and lower rates, "Clientelist Tie", that is the foundation to form political factions(Nathan, 1973; Nathan, 1978). Tang Tsou argues that the informal relationship affecting China's politics should not be limited to the vertical relations and the Parallel Relationship should be taken into consideration by the network of factional relations (such as the officials' relation of same level). Besides, he argues that "Faction" is too limited, without taking full consideration of the role of formal organizations in informal political struggle, and can by no means distinguish and demonstrate where the political faction comes from (formal or informal organizations). Thus, Tang Tsou advocates naming it Informal Groups or Political Action Groups (Tsou, 1976; Tsou, 1995). Lucian Pye proposes sectarian model to demonstrate their factional political views with the help of Chinese Political culture and he points out that Chinese culture, on one hand, stresses that leaders should be harmonious and on the other hand, emphasizes the subordinates' absolute loyalty to their superiors. Therefore, harmony on the surface and factional struggle in essence is China's main political power (Pye, 1980). After combining concepts of parties (mainly theories of Andrew Nathan, Tang Tsou and Lucian Pye), Lowell Dittmer further expands "Factional Politics" to "Informal Politics" (as proposed in this thesis). He points out that in China's politics, Relationship is the core of informal politics and in the analysis of China's political phenomenon, not only the factional interaction, but also the factors of informal politics and formal politics should be taken into consideration.(Dittmer, 1995)

As to "the causes of Factional Politics", from the perspective of political psychology, Lucian Pye believes that influenced by Chinese traditional culture and ethics, Chinese people have a distinctive feature---lack of the sense of security, which drives factional politics established by various relations in China's political ecology (Pye, 1980). After summing up the academic mainstream view, Kou Jianwen concludes that the causes of in formal politics are three views of "power struggle", "policy difference" and "interests conflict in bureaucratic organization", of which, the group supporting "power struggle" claims that the core of politics is power allocation and thus the struggle for power is the fundamental cause of China's informal political struggle; the group supporting "policy difference" believes that throughout our history, all inner party struggles are around guideline and thus "policy difference" is the main reason; the group supporting "interests conflict in bureaucratic organization", according to Western bureaucracy theory, holds that although factional conflicts are associated with power and policy, the profound reason is driven by interests of bureaucracy system.(Kou, 2010)

As to the "rules of factional conflict", after analyzing the struggle intensity and results, five major academic points of view are: "Code of Civility"(Note. 2) of Andrew Nathan, "Bandwagon" (in the reign of Chairman Mao) and "Balance of Power"(Note. 3) (after the reign of Chairman Mao) of Avery Goldstein, "Win-All"(Note. 4) of Tang Tsou and "Recurrence of Power Balance"(Note. 5) of Lowell Dittmer. 


\section{The Study Result in the Perspective of Informal Politics}

In the framework of informal political theory, Western scholars begin to view the Communist Youth League organizations and their cadres from the perspective of informal political theory and put forward "CYL (tuanxi)" and "Tuanpai"(Note 6) (the author prefers the name of "CYL" from Kou Jianwen, which will provide enough space for the study of the Communist Youth League out of "informal political theory" and "factional political theory"). Meanwhile, the research results mainly focus on officials above provincial-level in leading posts promoted from Communist Youth League organizations.

\subsection{The Definition of Study Objects of "CYL"}

As to the definition of study objects of "Tuanpai", Chen Li and Lyn White believe that they should be carders "who advanced their career through the Chinese Communist Youth League......" (Li, 2005) In related literature, the CYL carders are limited to those who have the Communist Youth League work experience and have been members of the Party Central Committee or above and mainly in Central Political Bureau with work experience in Youth League organizations. In Kou Jianwen's opinion, they should be "the secretariats in the Central Committee of CYL, ministers and deputy ministers in the Central Committee of CYL, the provincial party committee secretaries and deputy secretaries in CYL"(Kou, 2002). And then he modifies his view and put carders, after 1973, as "deputy department (bureau)" and above as the study objects. (Kou, 2007)

\subsection{Study Results of "CYL” Cadres}

Throughout the research literature of Communist Youth League in the Western mainstream, it can be concluded as follows (Li \& White, 2003; Li, 2003; Li, 2005; Li, 2006; Chou, 2007).

Firstly, compared with cadres of other factions, the average age of cadres in CYL is the lowest and the education level is highest (mainly with graduate degree). Among them, the main disciplines background involves economy, law, politics and other areas of the humanities and social science. Therefore, in general, the political development of cadres in CYL has tremendous potential.

Secondly, the group of cadres mainly work in the provincial party committees and governments, but are mainly limited in organization, propaganda, united front, discipline, education, etc., and few are in fields like foreign trade, foreign affairs, economy, finance, science and technology, etc., with certain limitations in career development, which ensures that the Communist Youth League is not the only one big faction and must share power and cooperate with other elite groups to ensure the diversity of China's political ecology.

Thirdly, from their growth background, most CYL cadres are from civilian families without prominent family background, revolutionary achievements, economic expertise, foreign expertise and forces support, thus with distinct Populism color. In participating policy making process, they tend to focus on social fairness and justice to obtain support of general public and social vulnerable groups.

\section{Doubt about "CYL" in Western countries}

The author believes that the research method of statistical analysis from the perspective of politics to study the Communist Youth League and the cadres is meaningful to improve the scientificalness, objectivity and prediction of study results. However, limited by false cognition to Chinese society, traditional ideas and the restriction of existing theory, the systemic changes since 30 years of Chinese reform and opening up are neglected; and over emphasis on "relationship" in Chinese political ecology and this factor taken into the decisive factor analysis will inevitably lead to the biased research on the Communist Youth League. The author will question the Western study of the Communist Youth League from theory applicability, objects selection and research methods as follows.

\subsection{Theory Applicability}

As stated in the dialectics that things are always dialectical unification, and is both formal and informal. There are in both China's regime and Western political system, just different in forms and degree. However, Western scholars see Chinese society with the knowledge of traditional communist countries, especially to study the Communist Youth League with the background that China society is the political ecology giving priority to "relationship". However, with 30 years of reform and opening up, either in perspectives of system or in law, Chinese society has developed a lot. Considering both the situation of China's political ecology and the main influence factors, institutional factor must be an important factor in author's opinion, and many Western scholars have perceived this erroneous zone and begin to study China's politics from institutional construction, besides the consideration of faction.(Bachman, 2001; Bachman, 1992; Dittmer, 2001)

In addition, the Communist Youth League and the cadres, in essence, are not in strict accordance with the 
informal political theory to delineate factions. Different from other factions, the identities of the Communist Youth League are multivariate and it is difficult to determine what specific group of cadres should be included in the CYL cadres and there will be an idealism error if they are forced to distinguish according to their faction. For example, as to deputy ministers in the Central Committee of CYL and the provincial party committee deputy secretaries in CYL, in Western literature, some are classified within the group of CYL cadres and are compared to leading figures, while some are not. In the analysis list of dividing CYL cadres, some cadres belong to the Communist Youth League cadres and have outstanding features of cadres in other classes. Therefore, it is questionable to study the Communist Youth League with informal political theory.

\subsection{Study Objects}

The limitation of the study objects will inevitably lead to poor understanding of the Communist Youth League. At this stage, the Western literature mainly focuses on "cadres above the bureau level" (while in American scholars' opinion, the study is only limited within leaders in the Central Committee of CYL and the provincial party committee secretaries in CYL). When it comes to participating in political activities, in our civil service system, cadres above "deputy division level" can transfer among units, institutions and state-owned enterprises. Meanwhile, the transfer phenomenon is relatively common and there are a large number of government cadres of division or even below in the Communist Youth League have been promoted to the provincial official list.(Note 7) If the Communist Youth League is only regarded as a place of factions, then the function of the Communist Youth League is inappropriately assessed.

At the same time, the evaluation results of cadres in the Communist Youth League from the perspective of factions lack objectivity. As a national youth organization, the Communist Youth League under the leadership of the Communist Party involves party and government organs, institutions, enterprises, colleges and universities, people's organizations and other social fields with a large number of cadres. If CYL cadres above division level are considered into the analysis system, the education of the Communist Youth League cadres is not only limited to the humanities and social science discipline and whether they are excellent in fields like foreign trade, economy, finance, technology and other aspects is unknown. If the Communist Youth League is viewed in informal political theory, it is hard to take directors of division into analysis system (because it is required that there is direct or indirect contact with faction leaders). However, if the Communist Youth League is studied as an institution from the perspective of organizational function, the analysis will be more accurate and objective.

\subsection{Study Method}

As to the study of the Communist Youth League in Western literature, there has been a horizontal comparative analysis (such as the comparative analysis between the CYL and other factions) instead of longitudinal comparative analysis. The research span is from 1978 to now, and cannot fully present how the Communist Youth League cadres are trained, as well as the development process. In the Western political literature, the study of the Communist Youth League is from General Secretary Hu served as secretary of the CYL Central Committee. The cadres before that period, especially the study of the Communist Youth League before the foundation of our country is little in our history. Therefore, the comparative analysis from the perspective of historical development is rare and the development history of the Communist Youth League cannot be fully presented, thus relevant institutional development course cannot be seen.

\section{Conclusion}

To sum up, it is significant for the Western political circles to study the Communist Youth League from informal political theory. However, due to the thinking set inherent and the limitations of theoretical study, the Western political circles rarely regard the Communist Youth League organizations as a complete and mature institution for selecting, training and delivering political elites and to explore their functions to update and renovate our political elites. The author believes that as the economic society develops, new elements emerge and timely and effective absorption of nascent elements within the system to avoid significant impact on the current system is an important criterion to measure the degree of a national political institutional process. (Huntington, 1965) Meanwhile, whether the political elites, as one of the most important factor of our ruling party (Seligman, 1950) and the whole society can effectively attract talented people into the rank of our party and to make them identity and develop our value concept is not only one of the most important tasks in front of us, but also is a political issue to be delved into by our political circles. The author hopes to embrace a brick to attract jade to call for more experts from the political point of view to study the Communist Youth League and to provide practical ideas and theoretical basis. 


\section{References}

Arendt, H. (1966). The Origins of Totalitarianism. New York: Harcourt, Brace \& World.

Bachman, D. (2001). The Paradox of Analyzing Elite Politics under Jiang. China Journal, (45), 95-100. http://dx.doi.org/10.2307/3182370

Bachman, D. (1992). The Limits on Leadership in China. Asian Survey, 32(11), 1046-1062. http://dx.doi.org/10.2307/2645270

Bo, Z. (2002). Chinese Provincial Leaders: Economic Performance and Political Mobility since 1949. Armonk, N.Y.: M.E. Sharpe.

Cherrington, R. (1997). Generational Issues in China: A Case Study of the 1980s Generation of Young Intellectuals. British Journal of Sociology, 48(2), 302-320. http://dx.doi.org/10.2307/591754

Dittmer, L. (1995). Chinese Informal Politics. China Journal, (34), 1-34. http://dx.doi.org/10.2307/2950131

Dittmer, L. (2001). The Changing Shape of Elite Power Politics. China Journal, (45), 53-67. http://dx.doi.org/10.2307/3182367

Friedirich, C., \& Brzezinski, Z. (1965). Totalitarian Dictatorship and Autocracy. Harvard University Press.

Huang, J. (2000). Factionalism in Chinese Communist Politics. Cambridge, UK; New York, NY: Cambridge University Press. http://dx.doi.org/10.1017/CBO9780511571688

Huntington, S. (1968). Political Order in Changing Societies. Harvard University, Center for International Affairs New Haven: Yale University Press.

Huntington, S. (1965, April). Political Development and Political Decay. World Politics, 387-430.

Kou, J. (2007). CYL Cadres Rising in the Era of Hu Jintao: Factional Considerations or Organizational Mission of Channeling cadres. Prospect Journal, 3(17), 77-116.

Kou, J. (2010). Zhong gong jing ying zheng zhi de yan bian: Zhi du hua yu quan li zhuan yi, 1978-2010. Taibei Shi: Wu nan tu shu chu ban gu fen you xian gong si.

Kou, J. (2011). Elite Recruitment and the Duality of the Chinese Party-state: The Mobility of Western-educated Returnee Elites in China, 1978-2008. In P. Hsu, S. Zhao, \& Y. Wu (Eds.), In Search of China's Development Model: Beyond the Beijing Consensus. Abingdon, Oxon; New York: Routledge.

Li, C., \& Lynn, W. (2003). The Sixteenth Central Committee of the Chinese Communist Party: Hu gets What? Asian Survey, 43(4), 553-597. http://dx.doi.org/10.1525/as.2003.43.4.553

Li, C., \& Lynn, W. (1988). The Thirteenth Central Committee of the Chinese Communist Party: From Mobilizers to Managers. Asian Survey, 28(4), 371-399. http://dx.doi.org/10.2307/2644734

Li, C., \& White, L. (1998). The Fifteenth Central Committee of the Chinese Communist Party: Full-fledged Technocratic Leadership with Partial Control by Jiang Zemin. Asian Survey, 38(3), 231-264. http://dx.doi.org/10.2307/2645427

Li, C. (2005). Hu's Policy Shift and the Tuanpai's Coming- of -Age. China Leadership Monitor, (15), 1-16.

Li, C. (2005). New chiefs: Hu's Groundwork for the 17th Party Congress. China Leadership Monitor, (13), 1-14.

Li, C. (2006). Reshuffling Four Tiers of Local Leaders: Goals and Implications. China Leadership Monitor, (18), $1-22$.

Li, C. (2005). Hu's Policy Shift and the Tuanpai's Coming- of -Age. China Leadership Monitor, (15), 1-16.

Li, C. (2003). The "New deal": Politics and Policies of the Hu Administration. Journal of Asian and African Studies, 38(4-5), 4-5. http://dx.doi.org/10.1177/002190960303800402

Nathan, A. J. (1973). A factionalism model for CCP politics. The China Quarterly.

Pye, L. (1976). Generational politics in a gerontocracy: The Chinese succession problem. Current Scene: Developments in Mainland China, 14(7), 1-9.

Pye, L. (1981). The Dynamics of Chinese Politics. Cambridge, Mass.: Oelgeschlager, Gunn \& Hain.

Schapiro, L. (1972). Totalitarianism. London: Pall Mall Press.

Seligman, L. (1950). The Study of Political Leadership. The American Political Science Review, 14(4), 904-915. http://dx.doi.org/10.2307/1951291 
Shambaugh, D. (2008). China's Communist Party: Atrophy and Adaptation. Washington, D.C.; Berkeley: Woodrow Wilson Center Press; University of California Press.

Tang, T. (1995). Chinese Politics at the Top: Factionalism or Informal Politics? Balance-of-Power Politics or a Game to Win All? China Journal, 34, 95-156.

Tsou, T. (1976). Prolegomenon to the Study of Informal Groups in CCP Politics. China Quarterly, 65. http://dx.doi.org/10.1017/S0305741000031799

Tucker, C. (1965). The Dictator and Totalitarianism. World Politics, 17(4), 555-583. http://dx.doi.org/10.2307/2009322

Yahuda, M. (1979). Political Generations in China. China Quarterly, 80. http://dx.doi.org/10.1017/S0305741000046051

Zang, X. (1991). Elite Formation and the Bureaucratic-Technocracy in Post-Mao China. Studies in Comparative Communism, 24(1), 114-123. http://dx.doi.org/10.1016/0039-3592(91)90024-Z

Zang, X. (1993). The Fourteenth Central Committee of the CCP: Technocracy or Political Technocracy? Asian Survey, 33(8), 787-803. http://dx.doi.org/10.2307/2645088

\section{Notes}

Note. 1. Data is from the history exhibition hall of the Communist Youth League network, and the website is http://www.gqt.org.cn/695/gqt_tuanshi/. In addition, other two large groups of people are All-China Federation of Trade Unions and All-China Women's Federation.

Note. 2. "The Principle of Etiquette" refers that, although there is outcome in sectarian fighting, the winner won't and does not have enough ability to eliminate the failure part. Please refer to Andrew Nathan, "A Factionalism Model for CCP Politics", pp. 46.

Note. 3. Goldstein believes that in the ruling era of Chairman Mao, due to surplus revolutionary achievements and personal charm without any factional or individual competition, Chinese political elites move closer to him; but after his death, the factions are in balance. The principle also gets the support of Lucian Pye. Pleases refer to

Goldstein: Avery Goldstein, From Bandwagon to Balance-of-power Politics: Structural Constraints and Politics in China, 1949-1978 (Stanford, California: Stanford University Press, 1991); Lucian W. Pye, "Factions and the Politics of Guanxi: Paradoxes in Chinese Administrative and Political Behaviour", China Journal, no. 34, July 1995, pp. 35-53.

Note. 4. "Winner Takes All" principle mainly refers to those, who win in the struggle, will get all the trophies (e.g., policy making, personnel appointment and removal), which also gets the support of Joseph Fewsmith. Please refer to Tang Tsou, "Chinese politics at the top", p.97; Joseph Fewsmith, Dilemmas of Reform in China: Political Conflict and Economic Debate (Armonk, New York: M.E. Sharpe),1994, pp.8-10.

Note. 5. "Recurrence of Power Balance" principle means that on the basis of Nathan's "Etiquette Principle", once official positions are deprived, the relationship network of this faction is easy to collapse. Therefore, with the appointment of the new leader, other new factions will enter the competition arena. Lowell Dittmer, "Chinese Informal Politics", pp.1-34.

Note. 6. The name of "CYL" derives from scholar Kou Jianwen and "Tuanpai" comes from American scholars such as Cheng Li, Lynn White, etc.

Note. 7. On this point, after reorganizing and summarizing resumes of Standing Committees of Party Committee in provinces issued by Chinese Communist Party News Network, the author has found that until October, 2007 (exclusive of the Army), around 19 committees have worked in the CYL Central Committee, around 57 committees have worked in the provincial League Committee, around 20 committees have worked in city League Committee, around 9 have worked in county League Committee, around 2 have worked in town (street), around 8 have worked in League Committee of government departments, around 15 have worked in League Committee of universities, around 9 have worked in League Committee of enterprises (factories) and around 9 have worked in League Committee of other grassroots' organizations. 


\section{Copyrights}

Copyright for this article is retained by the author(s), with first publication rights granted to the journal.

This is an open-access article distributed under the terms and conditions of the Creative Commons Attribution license (http://creativecommons.org/licenses/by/3.0/). 